MATEC Web of Conferences 6, 02003 (2013)

DOI: $10.1051 /$ matecconf/20130602003

(C) Owned by the authors, published by EDP Sciences, 2013

\title{
The impact of the amount of polypropylene fibres on spalling behaviour and residual mechanical properties of Reactive Powder Concretes
}

\author{
I. Hager ${ }^{\mathrm{a}}$, T. Zdeb and K. Krzemień \\ Institute of Building Materials and Structures Cracow University of Technology, 24, \\ Warszawska Str., 31-155 Kraków, Poland
}

\begin{abstract}
In this paper, an experimental study on the spalling behaviour and mechanical properties of Reactive Powder Concretes (RPCs) in high temperature are presented. The research program was established to evaluate the impact of low melting temperature polypropylene fibres PP on mechanical properties evolution with temperature but also to verify the effectiveness of their addition to prevent spalling. Three sets of RPC specimens were prepared for this study with different amount of PP fibres (no fibres, $1.0 \mathrm{~kg} / \mathrm{m}^{3}$ and $2.0 \mathrm{~kg} / \mathrm{m}^{3}$ ). The addition of PP fibres reduces the initial compressive strength of the RPC material by approx. $14 \%$ no significant influence on modulus of elasticity was observed. Addition of $1 \mathrm{~kg} / \mathrm{m}^{3}$ of PP fibres in RPC, seem not to give a sufficient protection against occurrence of spalling phenomenon. By adding $2 \mathrm{~kg} / \mathrm{m}^{3}$ of PP fibres the risk of spalling is significantly reduced.
\end{abstract}

\section{INTRODUCTION}

Reactive Powder Concrete (RPC) is a cement-based composite material in which the porosity is minimized by a low water to binder ratio, and its homogeneity is improved by the using fine aggregate. The density of packing the mixture of dry components is also optimised by the selection of precise gradiations of grains size. The microstructure of RPC is significantly modified by heat treatment - autoclaving or steam curing which allow getting a material with a compressive strength above $200 \mathrm{MPa}[1,2]$. Moreover, the reduction w/c ratio gives an extremely dense material, with reduced porosity and permeability. As the researches have proven sudden exposure to a high temperature of this type of material may lead to the spalling occurrence [3-5] most likely due to the internal gas pore pressure increase during heating.

The previous investigations of authors have shown, RPC subjected to different types of curing behaves in a different way when exposed to high temperature [5]. Water curing and low pressure steam cured RPCs spalled when heated with relatively slow heating rate of $1{ }^{\circ} \mathrm{C} / \mathrm{min}$. These observations led to the conclusion that it is essential to incorporate polypropylene fibres in low $w / c$ ratio cementitious materials at the mixing stage so providing a technological solution allowing the spalling risk to be reduced.

This paper is a continuation of previous works of the authors on the influence high temperature on the behaviour of Reactive Powder Concrete (RPC). The goal of this investigation was to study the impact of the addition of PP fibres in the various amount on the mechanical properties of RPC.

\footnotetext{
${ }^{a}$ e-mail: ihager@pk.edu.pl
}

This is an Open Access article distributed under the terms of the Creative Commons Attribution License 2.0, which permits unrestricted use, distribution, and reproduction in any medium, provided the original work is properly cited. 
Table 1. Reactive powder concretes mix compositions.

\begin{tabular}{|c|c|c|c|}
\hline Composition & RPC & RPC_1.0 & RPC_2.0 \\
\hline Cement CEM I 52.5R & \multicolumn{3}{|c|}{1.00} \\
\hline Silica fume & \multicolumn{3}{|c|}{0.20} \\
\hline Ground quartz 0/0.20 mm & \multicolumn{3}{|c|}{0.34} \\
\hline Quartz sand 0/0.50 mm & \multicolumn{3}{|c|}{0.81} \\
\hline Superplasticiser & \multicolumn{3}{|c|}{0.02} \\
\hline Water & \multicolumn{3}{|c|}{0.24} \\
\hline Polypropylene Fibres (PP) & 0 & 0.022 & 0.045 \\
\hline
\end{tabular}

\section{MATERIALS HEATING AND TESTING PROCEDURES}

In this research the Reactive Powder Concretes were manufactured using: Portland cement CEM I 52.5R, silica fume, grounded quartz $0 / 0.2 \mathrm{~mm}$, quartz sand $0 / 0.5 \mathrm{~mm}$ and acrylic-based superplasticizer with addition of 1.0 and $2.0 \mathrm{~kg} / \mathrm{m}^{3}$ of PP fibres. PB Eurofiber HPR polypropylene fibres with a diameter $15 \mu \mathrm{m}$ and length of $6 \mathrm{~mm}$ were used (dtex $=1.7 \mathrm{~g} / 10000 \mathrm{~m}$ ). According to the manufactures information these fibres present lower viscosity after melting compared with the standard PP fibres used to prevent spalling behaviour [6], thus better effectiveness of those fibres is expected in fire. The mix compositions of the tested RPCs are given in Table 1 . The concrete mixes were cast in steel moulds and densified gravitationally. For all tests, perpendicular specimens $0.04 \times 0.04 \times 0.08 \mathrm{~m}^{3}$ were employed. After the preliminary setting, at $20^{\circ} \mathrm{C}$, low-pressure steam curing at $90^{\circ} \mathrm{C}$ was applied during 24 hours.

After 90 days from casting, the specimens were heated to the target temperature of $200^{\circ} \mathrm{C}, 400^{\circ} \mathrm{C}$, $600^{\circ} \mathrm{C}, 800^{\circ} \mathrm{C}$ and $1000^{\circ} \mathrm{C}$. A heating rate of $0.5^{\circ} \mathrm{C} / \mathrm{min}$ was applied in all tests. After reaching the target temperature, it was maintained for 1 hour so that a homogenous temperature in the whole cross section of the specimen could be obtained. After cooling down, the specimens were tested in compression and the stress - strain relationship, compressive strength and modulus of elasticity were determined. For the strain measurements the magnetic clip-on extensometers were used.

The specimens were cooled down inside the furnace. Two specimens of each material per temperature were tested for mechanical tests. The change in modulus of elasticity $(E)$ with temperature was determined from $\sigma-\varepsilon$ curves. E value was calculated as the relationship between stress and strain in the range from $30 \%$ of the breaking stress and expressed in GPa.

The spalling tests consisted in heating rectangular specimens to the target temperature of $600{ }^{\circ} \mathrm{C}$ using different heating rates $0.5,1.0,2.0,4.0$ and $8.0^{\circ} \mathrm{C} / \mathrm{min}$ in the laboratory electric furnace. During the test, the concrete specimen was hung on a sling in the furnace and the mass of the specimen was continuously recorded during heating. The specimen's mass was recorded at intervals of 60 seconds, with an accuracy of $\pm 0.01 \mathrm{~g}$. The weight loss was then calculated and expressed as a percentage of the initial specimen mass. The temperature was measured using a type $\mathrm{K}$ thermocouple placed in proximity to the specimen's surface. All signals were recorded using a KD7 recorder. Measurements the weight loss accompanied by the temperature measurements is an effective method to define the temperature in which specimen spalled.

\section{TEST RESULTS AND DISCUSSION}

\subsection{Stress strain relationship, compressive strength and modulus of elasticity}

In Fig. 1 the representative stress strain relationships for each of the concretes tested are presented. The figures allow the influence of temperature on the mechanical properties to be analysed. With an increase in heating temperature a progressive change in the strength and stiffness of the concrete was observed. 

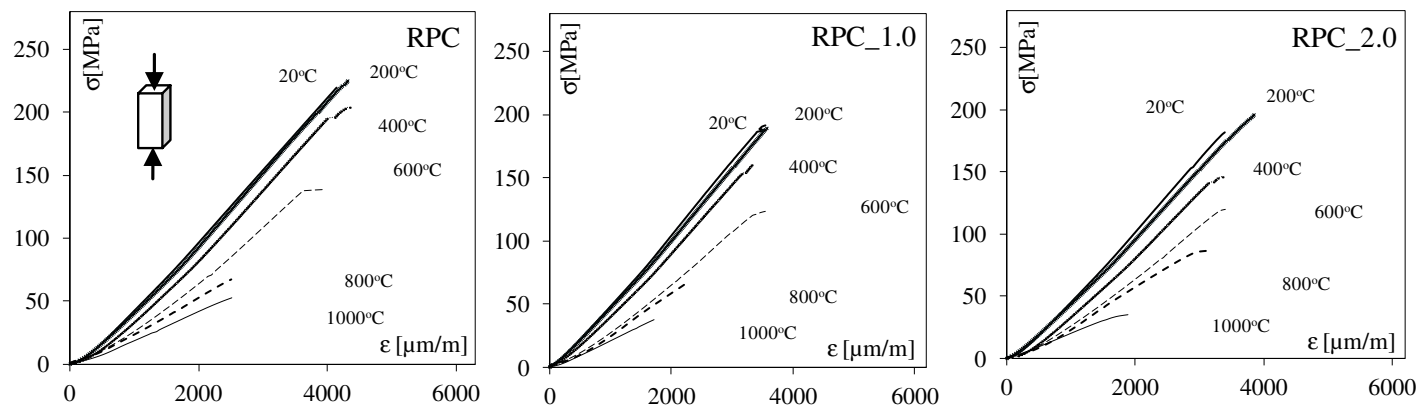

Figure 1. Representative stress - strain curves of heated RPC with $0.0,1.0$ and $2.0 \mathrm{~kg} / \mathrm{m}^{3}$ of PP fibres, tested in compression.

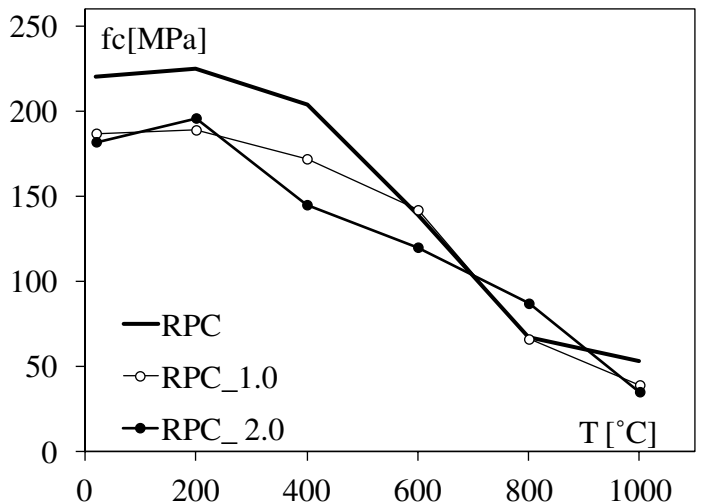

Figure 2. Influence of heating temperature on changes in the compressive strength of RPC and RPCs with PP fibres.

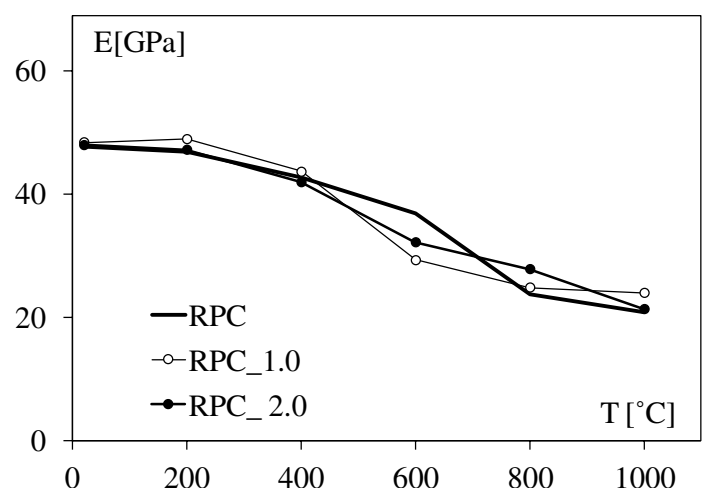

Figure 3. Influence of heating temperature on changes in the modulus of elasticity of RPC and RPCs with PP fibres.

Average values of compressive strength and modulus of elasticity for tested RPC are given in Fig. 2. and Fig. 3. The compressive strength of plain RPC was of $220 \mathrm{MPa}$ and for with PP fibres RPC_1.0 and RPC_2.0 was of $191 \mathrm{MPa}, 180 \mathrm{MPa}$ respectively. As a result the addition of PP fibres in the amount of $1.0 \mathrm{~kg} / \mathrm{m}^{3}$ or $2.0 \mathrm{~kg} / \mathrm{m}^{3}$ results in c.a. $14-18 \%$ reduction of compressive strength in comparison to the plain RPC.

Generally, heating induces a change in compressive strength and modulus of elasticity for all RPCs. However, RPCs heating to a temperature of $200^{\circ} \mathrm{C}$ results in a slight increase in strength (Fig 2). This occurrence was attributed to the phenomenon of internal autoclaving. Moisture is transformed into water vapour due to heating. In these conditions chemical and physical changes may take place. The process of simultaneously exposing the material to high pressure and temperature is a well-known technology in the prefabrication of concrete. This procedure may well activate changes in the microstructure of hydrates and often increases concrete strength.

Furthermore, exposure to a temperature higher than $400^{\circ} \mathrm{C}$ results in a significant strength reduction. When the heating temperature increases further strength decrease of strength was observed. RPC_1.0 heated to $600{ }^{\circ} \mathrm{C}$ presents $75 \%$ of the initial strength. This reduction is even higher for RPC_2.0 in which only $65 \%$ of the strength of the untreated concrete is present after heating to $600{ }^{\circ} \mathrm{C}$. This reduction in strength may be caused by the cracking of the cement paste around quartz aggregates which expand at $574{ }^{\circ} \mathrm{C}$ due to the transformation from $\beta$ quartz to $\alpha$ quartz. There is a large quantity of quartz in RPC due to the addition of ground quartz. Additionally, the cracking of the cement paste also results from shrinkage due to progressive dehydration. It is worth noting that for the temperatures higher than $600{ }^{\circ} \mathrm{C}$ 


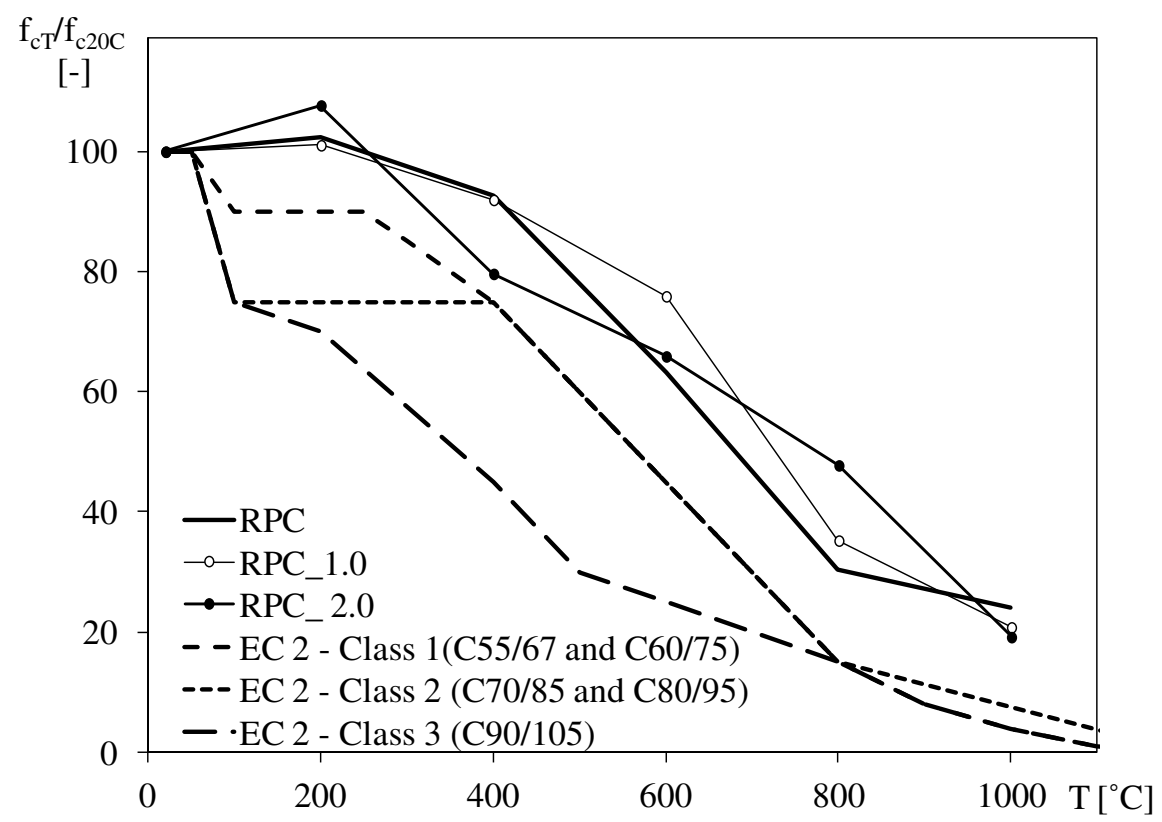

Figure 4. Relative changes of compressive strength for tested RPCs compared with EC 2 recommendations.

for all three concretes strength values are almost the same regardless the amount of fibres that were added.

The higher amount of fibres seems not to influence the strength in non heated material. When heated, only for temperatures 400 and $600{ }^{\circ} \mathrm{C}$ we may consider lower values of compressive strength for RPC_2.0 compared with RPC_1.0. Further heating results in a systematic reduction of strength, which is mainly due to the cracking and further CSH gel dehydration.

The values of the modulus of elasticity as a function of temperature of plain RPC and RPC with PP fibres are presented in Fig. 3. The initial values of the modulus of elasticity in the plain RPC and for the RPC_ 1.0 and RPC_2.0 were similar and equal to $50 \mathrm{GPa}$. The addition of PP fibres does not result in a change of stiffness described as an $E$ value. For all RPC Young's modulus values do not vary significantly in whole range of temperature. It can also be observed that above a temperature of $200^{\circ} \mathrm{C}$ heating results in a decrease in the modulus of elasticity for all RPCs and all three curves follow the same scheme (Fig. 3).

Figure 4 allows relative's values of compressive strength changes comparison with Eurocode 2 recommendations. In whole range of temperatures $f_{c T} / f c_{20}{ }^{\circ} \mathrm{C}$ curves for RPC, RPC_1.0 and RPC_2.0 are located above the values defined for a Class 1, Class 2 and Class 3 concrete. Those comparisons should be treated with precaution for the reason that EC recommendations are based on hot tested material results and as the results presented in Pimienta et al. [7] have shown hot tested compressive strength of ultra high performance fibre reinforced concretes (UHPFRC - Ductal) values are lower than those obtained after cooling down. That is in opposite to results that are observed for conventional concretes, where hot tested $f_{c T}$ values are usually higher than those observed after cooling down [8]. A supplementary work is required in this field.

\subsection{Weight loss and spalling test results}

Five heating rates $0.5,1.0,2.0,4.0$ and $8.0^{\circ} \mathrm{C} / \mathrm{min}$ were applied to heat RPCs specimens. All specimens were heated to the target temperature of $600^{\circ} \mathrm{C}$. The weight loss along with the temperature 

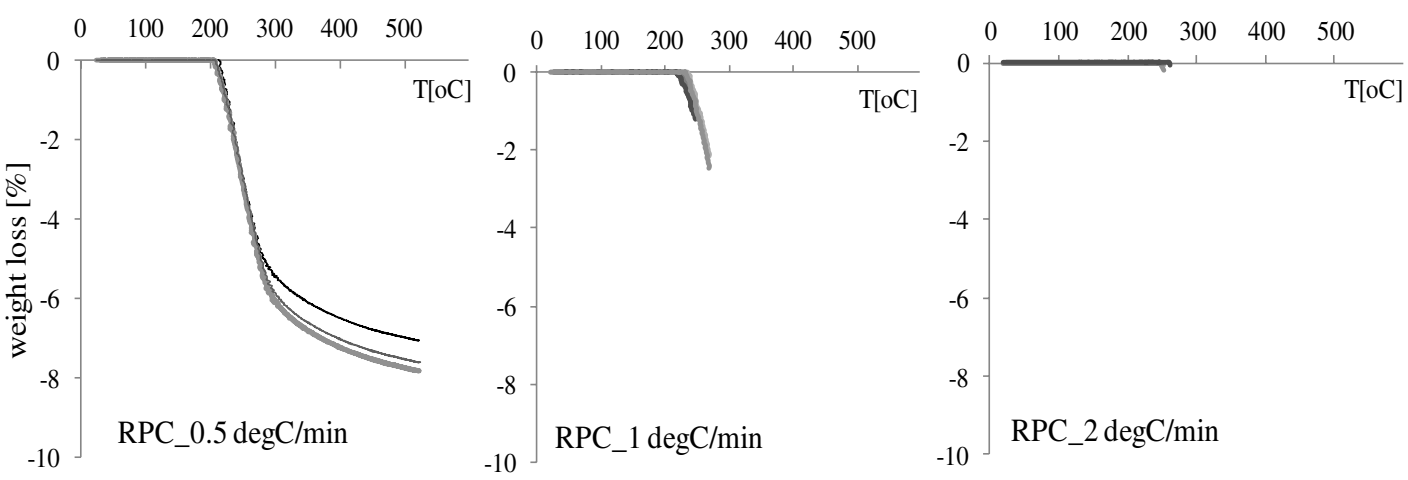

Figure 5. Weight loss measurement during heating of plain RPC. Heating ratio $0.5^{\circ} \mathrm{C} / \mathrm{min}, 1.0^{\circ} \mathrm{C} / \mathrm{min}$ and $2{ }^{\circ} \mathrm{C} / \mathrm{min}$.

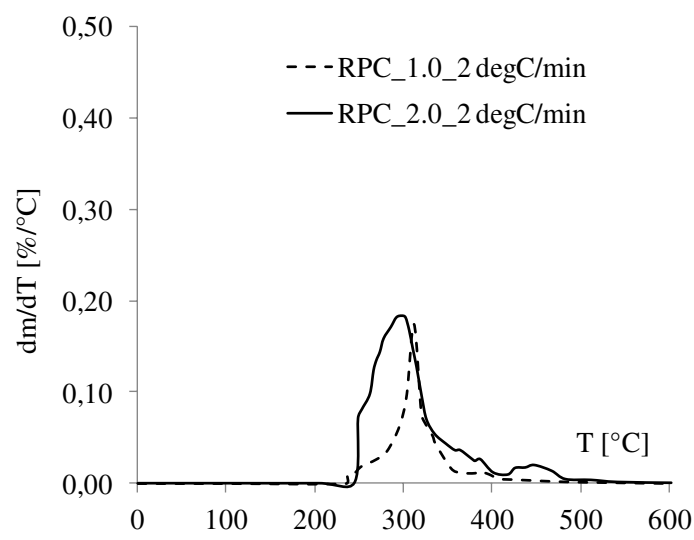

Figure 6. Rate of weight loss of RPC with $1.0 \mathrm{~kg} / \mathrm{m}^{3}$ and $2.0 \mathrm{~kg} / \mathrm{m}^{3}$ heated to $600{ }^{\circ} \mathrm{C}$. Heating ratio $2.0^{\circ} \mathrm{C} / \mathrm{min}$.

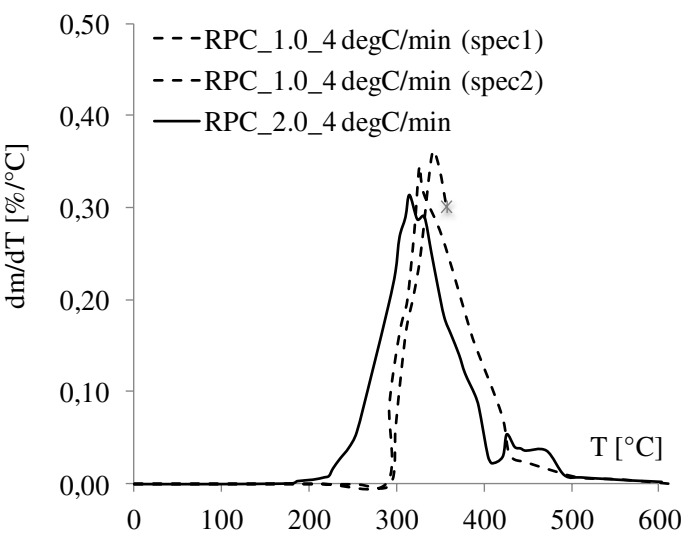

Figure 7. Rate of weight loss of RPC with $1.0 \mathrm{~kg} / \mathrm{m}^{3}$ and $2.0 \mathrm{~kg} / \mathrm{m}^{3}$ heated to $600^{\circ} \mathrm{C}$. Heating ratio $4.0^{\circ} \mathrm{C} / \mathrm{min}$.

measurements allowed the determination of the spalling temperature. In Fig. 5 weight loss results of plain RPC heated with $0.5,1.0,2.0^{\circ} \mathrm{C} / \mathrm{min}$ are presented.

During slow heating - a rate of $0.5^{\circ} \mathrm{C} / \mathrm{min}$ - none of four RPC specimens spalled. The increase of the heating rate to $1.0{ }^{\circ} \mathrm{C} / \mathrm{min}$ induced thermal instability and the spalling temperatures were respectively of $T_{\text {spall }}=241,261,254,241^{\circ} \mathrm{C}$. As it might be expected further increase of heating rate $\left(2{ }^{\circ} \mathrm{C} / \mathrm{min}\right)$ also resulted in spalling behaviour of plain $\operatorname{RPC}\left(T_{\text {spall }}=253,262,253,261^{\circ} \mathrm{C}\right)$. As it may be observed in the Fig. 5 sudden explosion occurs when the temperature near the surface of the specimen reached $250^{\circ} \mathrm{C}$, practically without mass change.

For RPCs with PP fibres during slow heating with the heating rate of $0.5^{\circ} \mathrm{C} / \mathrm{min}$ and $1.0{ }^{\circ} \mathrm{C} / \mathrm{min}$ none of RPC specimens spalled regardless of the amount of added PP fibres. Also when the heating rate was doubled to $2.0^{\circ} \mathrm{C} / \mathrm{min}$ the spalling phenomenon did not appear. However, when the heating rate of $4{ }^{\circ} \mathrm{C} / \mathrm{min}$ was applied, one of two tested specimens RPC_1.0 had spalled and none of RPC_2.0 did. In Fig. 6 and Fig. 7 one can analyse the rate of weight loss for tested RPC modified with the addition of PP fibres. From those pictograms it can be concluded that higher amount of PP fibres allow easier water/gas evacuation. What's more the temperature in which the intensive water evacuation takes place is lower for RPC_2.0. 


\section{MATEC Web of Conferences}

Table 2. Spalling test results for plain RPC and RPC modified with PP fibres.

\begin{tabular}{|l|c|c|c|c|c|}
\hline \multirow{2}{*}{ RPC } & \multicolumn{5}{|c|}{ heating rate } \\
\cline { 2 - 6 } & $0.5^{\circ} \mathrm{C} / \mathrm{min}$ & $1.0^{\circ} \mathrm{C} / \mathrm{min}$ & $2.0^{\circ} \mathrm{C} / \mathrm{min}$ & $4.0^{\circ} \mathrm{C} / \mathrm{min}$ & $8.0^{\circ} \mathrm{C} / \mathrm{min}$ \\
\cline { 2 - 6 } & \multicolumn{4}{|c|}{ Spalling: yes/no; [no tested specimens/specimens that spalled]; (spalling temperature $\left.\mathrm{T}_{\text {spall }}\right)^{* *}$} \\
\hline \multirow{2}{*}{ RPC } & no $\left[10^{*} / 0\right]$ & $\begin{array}{c}\text { yes }[4 / 4] \\
(241,261,254, \\
\left.241^{\circ} \mathrm{C}\right)\end{array}$ & $\begin{array}{c}\text { yes }[4 / 4] \\
(253,262,253, \\
\left.261{ }^{\circ} \mathrm{C}\right)\end{array}$ & - & - \\
\hline RPC_1.0 & no $\left[10^{*} / 0\right]$ & no $[2 / 0]$ & no $[2 / 0]$ & $\begin{array}{c}\text { yes }[2 / 1] \\
\left(331^{\circ} \mathrm{C}\right)\end{array}$ & $\begin{array}{c}\text { yes }[2 / 2] \\
\left(354,348^{\circ} \mathrm{C}\right)\end{array}$ \\
\hline RPC_2.0 & no $\left[10^{*} / 0\right]$ & no $[2 / 0]$ & no $[2 / 0]$ & no $[2 / 0]$ & no[2/0] \\
\hline
\end{tabular}

*Specimens heated for mechanical tests with no weight loss determination.

**Spalling temperature measured wit type $\mathrm{K}$ thermocouple near the surface of the specimen.

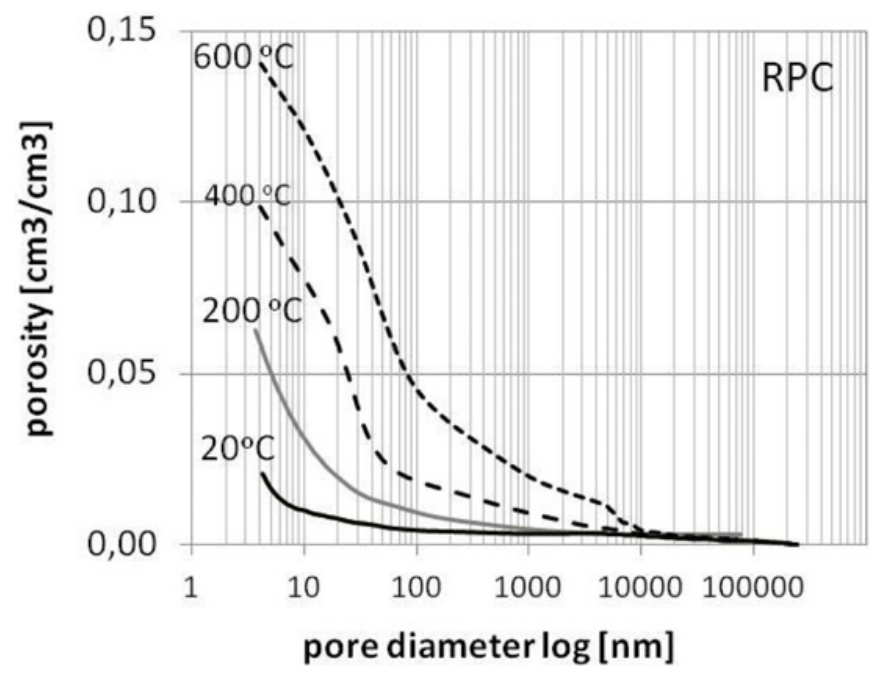

Figure 8. Effect of heating on cumulative pore volume of plain RPC heated to $200^{\circ} \mathrm{C}, 400^{\circ} \mathrm{C}$, and $600{ }^{\circ} \mathrm{C}$, compared with a non heated specimen $\left(20^{\circ} \mathrm{C}\right)$.

All spalling results obtained with different heating rates are summarised in Table 2. From these results it can be concluded that an amount of $2.0 \mathrm{~kg} / \mathrm{m}^{3}$ seems to be sufficient to prevent spalling in $\mathrm{RPC}$ when the heating rate is as high as $8^{\circ} \mathrm{C} / \mathrm{min}$. Greater heating speed were not investigated for the reasons of technical limitations of the heating system.

\subsection{Material porosity and SEM observations}

In order to explain the observed changes in mechanical properties, tests were carried out to determine the effect of heating on cumulative pore volume of plain RPC. The microporosity results determined by the mercury intrusion method are shown in Fig. 8 after heating to $200{ }^{\circ} \mathrm{C}, 400{ }^{\circ} \mathrm{C}$ and $600{ }^{\circ} \mathrm{C}$ compared with non heated concrete $\left(20^{\circ} \mathrm{C}\right)$.

The dehydration process occurring in the $\mathrm{CSH}$ gel reduces its volume, which in turn increases the porosity of the cement matrix. Moreover, during heating, the cement paste experiences a slight expansion up to a temperature of approximately $200^{\circ} \mathrm{C}$, although intense shrinkage begins as soon as this temperature has been exceeded. This significantly contributes to the porosity evolution of the RPC's 
cement paste. Heating mainly results in an increase in microporosity seen in the range of pores with a size below $10000 \mathrm{~nm}$. Due to heating, the total pore volume increases from $0.02 \mathrm{~cm}^{3} / \mathrm{cm}^{3}$ for unheated material to $0.14 \mathrm{~cm}^{3} / \mathrm{cm}^{3}$ when heated to $600^{\circ} \mathrm{C}$.

\section{CONCLUSIONS}

On the basis of the results presented and their analysis, the following conclusions can be drawn:

- The addition of PP fibres added in the amount of $2.0 \mathrm{~kg} / \mathrm{m}^{3}$ PP fibres allows to limit the spalling risk of RPC cementitious material. Spalling was efficiently limited even when the relatively high heating rate is applied $8^{\circ} \mathrm{C} / \mathrm{min}$;

- Lower amount of PP fibres $1 \mathrm{~kg} / \mathrm{m}^{3}$ do not efficiently prevented spalling to occur;

- The rate of weight loss results allowed to observe that higher amount of PP fibres allow easier water and gas evacuation. The temperature in which the intensive water evacuation takes place is lower for RPC with 2.0 of PP fibres;

- The addition of PP fibres characterised by a low viscosity at melting, in amount of $2 \mathrm{~kg} / \mathrm{m}^{3}$, results in a $18 \%$ reduction in compressive strength compared with plain RPC;

- The quantity of polypropylene fibres added $\left(1.0\right.$ and $\left.2.0 \mathrm{~kg} / \mathrm{m}^{3}\right)$ does not influence significantly the changes in relative compressive strength as a function of temperature. The compressive strength changes of plain RPC and RPC with PP fibres present a similar character as a function of heating temperature;

- Modulus of elasticity of non heated RPC material was the same regardless the amount of PP fibres added. The polypropylene fibres do not influence the material stiffness in whole range of tested temperature;

- The RPC porosity results determined with the mercury method show that total pore volume increases from $0.02 \mathrm{~cm}^{3} / \mathrm{cm}^{3}$ to $0.14 \mathrm{~cm}^{3} / \mathrm{cm}^{3}$ when heated to $600^{\circ} \mathrm{C}$.

The study was supported by the Polish National Research Centre (Grant N N506 045 040).

\section{References}

[1] T. Zdeb and J. Śliwiński, "The influence of steel fibre content and curing conditions on mechanical properties and deformability of reactive powder concrete at bending," in Proc. of the 9th Int. Symp. "Brittle Matrix Composite 9", eds. A.M. Brandt, J. Olek and I.H. Marshall, p 33-42, Warsaw, October 2009.

[2] S. Collepardi, L. Coppola, R. Troli and M. Collepardi, "Mechanical Properties of Modified Reactive Powder Concrete," American Concrete Institute, 173, 1997, pp. 1-22.

[3] C.-T. Liu and J.-S. Huang, "Fire performance of highly flowable reactive powder concrete," Construction and Building Materials, pp. 2072-2079, 23 (2009).

[4] G. Peng, Y. Kang, X. Liu, Q. Chen and J. Zhao, "Explosive spalling and residual mechanical properties of reactive powder concrete subjected to high temperature," in Proceedings of 2nd International RILEM Workshop on Concrete Spalling Due to Fire, ed. F. Dehn, E.A.B. Koenders, 5-7 October 2011, Delft, 2011.

[5] I. Hager and T. Zdeb, "Influence of curing conditions on spalling behaviour of Reactive Powder Concretes," in Proceedings of 2nd International RILEM Workshop on Concrete Spalling Due to Fire Exposure, ed. F. Dehn, E.A.B. Koenders, pp. 377-383, Delft, The Netherlands, 5-7 October 2011. 


\section{MATEC Web of Conferences}

[6] I. Knack, "The use of PP fibers in construction to avoid explosive concrete spalling in case of fire. New test results for the clarification of the mode of action," in 2nd International RILEM Workshop on Concrete Spalling Due to Fire Exposure, ed. F. Dehn, E.A.B. Koenders, 5-7 October 2011, Delft, 2011.

[7] P. Pimienta, J.-C. Mindeguia, A. Simon and M. Behloul, "Behaviour of 2 UHPFRC at High Temperatures," in International Workshop on Ultra High Performance Fibre Reinforced Concrete (UHPFRC) - Designing and Building art and Development, Marseill, France, November 17th-18th $2009 .$.

[8] I. Hager and P. Pimienta, "Mechanical properties of HPC at high temperatures," in Proc. Int. Workshop fib Task Group, Fire Design of Concrete Structures: What now? What next?, Milan, 2004. 